Article

\title{
Analysis and Modeling of the Wear-Out Process of a Lithium-Nickel-Manganese-Cobalt Cell during Cycling Operation under Constant Load Conditions
}

\author{
Damian Burzyński *, Robert Pietracho®, Leszek Kasprzyk and Andrzej Tomczewski \\ Institute of Electrical Engineering and Electronics, Poznan University of Technology, Piotrowo 3A, \\ 60-965 Poznan, Poland; robert.pietracho@put.poznan.pl (R.P.); leszek.kasprzyk@put.poznan.pl (L.K.); \\ andrzej.tomczewski@put.poznan.pl (A.T.) \\ * Correspondence: damian.burzynski@put.poznan.pl
}

Received: 14 September 2019; Accepted: 14 October 2019; Published: 15 October 2019

check for updates

\begin{abstract}
This article describes the analyses of modeling the wear process of lithium-nickel-manganese-cobalt cells operating cyclically under constant load conditions. The main aging processes taking place in cells and the methodology of the modeling are discussed. The process of cell wear is examined, taking into account the influence of cyclic operating parameters (temperature, discharge current, and discharge depth). On the basis of the analyses carried out, a new function reflecting the influence of ambient temperature on the durability of the cell is proposed. A new fuzzy model of the wear process of the NMC 18650 type cell, depending on the parameters of the discharge half cycle, has been developed. The results of the model have been verified by experimental research.
\end{abstract}

Keywords: lithium-ion cell life; battery modeling; cycle life modeling; fuzzy modeling

\section{Introduction}

The first electrochemical cells were designed, built and described more than 200 years ago, but it was only in the last three decades that the emergence of lithium-ion cells contributed to the dynamic growth of their popularity. The areas of their application are constantly expanding, and the most common are currently mobile electronic devices, various types of e-mobility solutions (especially electric vehicles), uninterruptible power supply systems, and systems cooperating with renewable sources of electricity [1]. Where the cost of cell purchase is significant and the load is characterized by high dynamics of change, the analysis of cell behaviour, both in electrical and thermal aspects, is very important [2,3]. For this purpose, various types of cell models are being developed all over the world, the most popular of which are electrochemical [4,5] and circular [6-8] models. At their core, all kinds of battery management systems are functioning, which allows the prediction of currents and voltages at cell terminals and the state of charge, while they control the charging process in a way that ensures safety. Without such systems, the cells could wear out excessively.

Another very important aspect of cell modeling is determining the state of health $(\mathrm{SOH})$ of cells, both for economic and ecological reasons. Up-to-date research on this issue is important, because knowledge of the cell wear process can be used to design systems powered by electrochemical energy storage to optimize their operation, extend the time of proper battery operation, and thus reduce the consumption of rare earth elements. For this reason, many papers on modeling the process of lithium-ion battery consumption are found in the literature [9-12].

In this work, we focused on the issue of modeling the $\mathrm{SOH}$ of lithium-ion NMC cells. Due to the fact that for most types of cells, ageing models during storage are already developed [13,14], this paper deals with the issue of modeling the process of lithium-ion cell wear resulting from cyclic operation. 
The analysis of cell wear resulting from cyclic operation should take into account many factors that have a significant impact on its $\mathrm{SOH}$, related to temperature, electric field strength and current density in the electrolyte, double layers, and electrodes [15]. The issue is also hampered by the fact that the nature of this impact is strongly nonlinear. Therefore, in some works, numerous simplifications of the models were made, for example, [16] reported that during $\mathrm{SOH}$ modeling it is mainly the amount of electric charge exchanged by the cell that must be taken into account. In $[17,18]$, models of cell $\mathrm{SOH}$ were proposed for cells operating at a constant temperature or under a constant load. Many sources suggest taking into account different operating parameters, but assume only their averaged values during the cycle. In [9], it was assumed that the effect of temperature on $\mathrm{SOH}$ is a polynomial of the third order, whereas discharge currents, charging currents, and depth of discharge $(D O D)$ are exponential or power $[11,19]$. For the average state of charge $\left(S O C_{a v g}\right)$, linear or polynomial functions of the second order are assumed [16,20]. In [20], it was indicated that when the cell is operating with a dynamically changing load, the $D O D$ changes should be considered separately for the charging and discharging processes. In [21], the nonlinear influence of the value of the charging current was also proved. The aforementioned works either lack consideration of important parameters of cell cyclic operation or address them too narrowly. It is against this background that we undertook to develop a model of cell wear process depending on ambient temperature, the value of discharge current, and the depth of discharge.

Taking all these parameters into account makes the identification of model coefficients difficult and time-consuming. A certain solution to the problem of creating complex mathematical functions, enabling the analysis of cell ageing, and determining the coefficients of these functions is the use of fuzzy logic. For this reason, we proposed the use of a fuzzy Mamdani system to analyze the state of consumption, which is a new approach to issues related to the modeling of the consumption of lithium-ion cells.

\section{Aging Processes in Lithium-Ion Cells}

Aging processes take place throughout the life cycle of lithium-ion cells, both in cyclic operation mode and in the storage state. These processes take place in the whole of the cell area, i.e., on the electrodes, in the electrolyte, and in the contact area between the phases of the electrodes and the electrolyte. According to many research papers, at least a dozen aging processes may be indicated, and their causes may have different physical characters (e.g., thermal, chemical, and electrochemical) [22,23]. Table 1 presents the dominating aging processes occurring in lithium-ion cells as a result of electrochemical processes.

Table 1. Main aging processes taking place in lithium-ion cells (Adapted from [24]).

\begin{tabular}{cc}
\hline No. & Name of Process \\
\hline 1 & Formation, build-up, fracture and reformation of the solid electrolyte interphase (SEI) \\
2 & Corrosion of the current collector \\
3 & Decomposition and fracture reaction of the electrolyte and binder \\
4 & Viscoelastic creep of the separator \\
5 & Lithium plating \\
6 & Gassing of the particles \\
\hline
\end{tabular}

The processes listed in Table 1 occur as a result of the electric charge flow during cyclic cell operation (charging and discharging processes). The speed of these processes is affected by the following cyclic operating parameters: cell temperature $(T)$, charging current $\left(I_{c h}\right)$, discharge current $\left(I_{d}\right)$, discharge depth, and average state of charge of the cell. The aging processes responsible for the formation and subsequent evolution of the SEI layer are caused, among other things, by the use of the cell in the wrong voltage range (the high value of the final charging voltage is particularly unfavourable), the cell temperature, and the high current values during charging and discharging. 
Corrosion of the current collector is caused by deep discharge of the cell (below the final discharge voltage), overcharging of the cell (above the final charging voltage), and storing the cell in an elevated ambient temperature. Conversely, the process of lithium plating of the cell is mainly caused by cyclic work in low temperatures. This process can be intensified if the charging current is high in these conditions. In the decomposition and fracture reactions of the electrolyte and binder, high temperatures and pressures in the cell, operating with a high state of charge of the cell (SOC), and overcharging of the cell can be triggers. Gassing occurs especially in the final phase of cell charging. The higher the temperature of the cell and the higher the charging current, the more intensively this process occurs. Aging processes can also be caused by various types of mechanical damage to the cell structure, for example, vibration or high pressure [25]. They can lead to viscoelastic creep of the separator. The use of mechanically damaged cells is particularly dangerous. In addition to the unstable operation of the cell in these situations, there is also a high risk of fire. Without interfering with the structure of the cell, the effects of these processes can only be analyzed by parameters such as internal resistance (growth) and capacity (atrophy).

\section{Modeling the Wear Process of Lithium-Ion Cells}

The following parameters can be taken as measures of the wear of cells ( $\mathrm{SOH}$, state of health):

- loss of cell capacity (as a result of gradual loss of capacity to accumulate electric charge);

- increase of internal resistance [26] (in some applications it is assumed that the cell is worn out when internal resistance doubles in relation to the resistance of the new cell);

- number of complete charge and discharge cycles $(\mathrm{N})$ the cell can complete before cell capacity loss reaches 20\% (criterion used for electric vehicles according to ISO 124052);

- $\quad$ exploitation time (applies to aging resulting from storage time).

Modeling of the wear process of lithium-ion cells is divided into two stages, during storage and during cyclic operation. In the first case, the charging state and ambient temperature are factors that have a particular impact on the wear of the cells. In the case of cyclic operation, the factors to be taken into account in the model are cell temperature, and discharge and charging currents (DOD).

In order to model the process of cell wear, the current international literature often uses mathematical multiplication models expressed in general form by means of the following equation $[11,19,20,27]$ :

$$
\operatorname{SOH}\left(T, I_{d}, I_{c h}, D O D\right)=f(T) \cdot f\left(I_{d}\right) \cdot f\left(I_{c h}\right) \cdot f(D O D)
$$

where $\mathrm{SOH}$ is the state of health of the cell, $f(T)$ is the function describing the impact of temperature, $f\left(I_{d}\right)$ is the function describing the impact of discharging current, $f\left(I_{c h}\right)$ is the function describing the impact of charging current, and $f(D O D)$ is the function describing the impact of depth of discharge.

A model which allows for the estimation of the number of performed full equivalent cycles and useful capacity as the function of the depth of discharge, temperature, and load was developed in [9]. In this model, the impact of cycling on the useful capacity of the cell is described by the following equation [9]:

$$
Q(n)=Q_{B O L}-\varepsilon(n) \cdot\left(Q_{B O L}-Q_{E O L}\right)
$$

where $n$ is the cycle number, $Q_{B O L}$ is the capacity at beginning of life (new cell) (Ah), $\varepsilon$ is the aging factor (-), and $Q_{E O L}$ is the capacity at end of cell life (Ah).

The cell aging factor $\varepsilon(n)$ is determined according to the following formula [9]:

$$
\varepsilon(n)=\varepsilon(n-1)+\frac{0.5}{N(n-1)}\left(2-\frac{D O D(n-2)+D O D(n)}{D O D(n-1)}\right)
$$

where $N$ is the maximum number of cycles (-). 
The maximum number of cycles can be calculated from the following relationship [9]:

$$
N(n)=H\left(\frac{D O D(n)}{100}\right)^{-\xi} \exp \left(-\psi\left(\frac{1}{T_{r e f}}-\frac{1}{T_{a}(n)}\right)\right) \cdot\left(I_{d \_a v g}(n)\right)^{-\gamma_{1}}\left(I_{\text {ch_avg }}(n)\right)^{-\gamma_{2}}
$$

where $H$ is the cycle number constant (-), $\xi$ is the constant related to DOD (-), $\psi$ is the Arrhenius rate for cycle number (-), $I_{d \_a v g}$ is the average discharge current in half-cycle duration (A), $I_{\text {ch_avg }}$ is the average charge current in half-cycle duration (A), $\gamma_{1}$ is the constant related to discharge current $(-), \gamma_{2}$ is the constant related to charge current $(-), T_{r e f}$ is the nominal temperature $\left({ }^{\circ} \mathrm{C}\right)$, and $T_{a}$ is the ambient temperature $\left({ }^{\circ} \mathrm{C}\right)$.

The above model assumes that the $D O D$ for the discharge process is the same as for the charging process. Cui et al. [19] developed a model of capacity atrophy for $\mathrm{LiCoO}_{2}$ cells depending on temperature $(T)$, discharge current $(C), D O D$, upper cut-off voltage $\left(V_{t}\right)$, and number of cycles. This model is only suitable for shallow discharges and low load currents. Capacity loss is determined on the basis of equations [19]:

$$
\begin{gathered}
Q_{\text {loss }}\left(T, C, D O D, V_{t}, n\right)=A\left(D O D, C, V_{t}\right) \cdot \exp \left(-\frac{E_{a}(C)}{8.314 \cdot T}\right) \cdot n^{0.74} \\
A\left(D O D, C, V_{t}\right)=-157.671+3.624 \cdot D O D+14.19 \cdot C+2.721 \cdot \exp \left(0.938 \cdot V_{t}\right)
\end{gathered}
$$

where $E_{a}$ is the activation energy (J), $n$ is the number of cycles (-), $A$ is the pre-exponential factor (-). Where the cell is dynamically loaded with a variable load, $D O D$ changes should be considered separately for the charging and discharging processes. Then, the analytical formula can be very complex, as in [20], in which the number of cycles that a lithium-ion cell can perform is determined by the relation:

$$
\begin{aligned}
& N\left(I_{C H}, I_{D}, \Delta D O D, S O C, T\right)=N_{0}\left[2:\left(\frac{1}{a_{C H} \exp \left(\frac{b_{C H} I_{C H}}{C_{n}}\right)}+\frac{1}{a_{D} \exp \left(\frac{-b_{D} \cdot I_{D}}{c_{n}}\right)}\right)\right] . \\
& \cdot \frac{a_{\Delta \mathrm{DOD}}}{\Delta \mathrm{DOD}_{\mathrm{D}}^{\mathrm{b}_{\Delta \mathrm{DOD}}+\Delta \mathrm{DOD}_{\mathrm{CH}}^{\mathrm{b}} \triangle \mathrm{DOD}}} \cdot\left(c_{S O C} S O C_{a v g}^{2}+b_{S O C} S O C_{a v g}+a_{S O C}\right) \cdot\left(d_{T} T^{3}+c_{T} T^{2}+b_{T} T+a_{T}\right)
\end{aligned}
$$

where $N_{0}$ is the constant depending on the analyzed cell, adjusting the obtained result to the number of cycles at rated conditions; $\triangle D O D_{C H}$ is the change in the discharge depth (relative amount of electric charge delivered) during charging; $\triangle D O D_{D}$ is the change in the discharge depth (relative amount of electric charge taken out) during discharge; $a, b, c, d$ are the coefficients depending on the analyzed cell, with indexes related to cyclic model parameters; and $C_{n}$ is the rated capacity of the cell.

\section{Analysis of the Impact of the Cycle Operation Parameters on the Wear-Out of the NMC Cell}

Developing an aging model of a lithium-ion cell operating cyclically requires knowledge of the influence of individual operating parameters (temperature, charging and discharging currents, depth of discharge, and average state of charge) on the process of cell wear. A commercial 18650 lithium-nickel-manganese-cobalt (NMC) cylindrical cell with a nominal capacity of $2600 \mathrm{mAh}$ was selected for the capacity consumption analysis. Taking into account that aging tests are time-consuming (especially the variants with reduced $D O D$ may last up to several months), it was decided to carry them out under accelerated aging conditions. This means that for cyclic operating parameters, the cell was selected with values exceeding its ratings. The values of cyclic operating parameters selected during the tests are presented in Table 2. The variants related to the influence of $S O C_{\text {avg }}$ and charging current values have been omitted. In the implemented variants, the cells were charged with a constant current of a constant average value of $0.85 \mathrm{C}$. 
Table 2. Values of cyclic operating parameters of tested cell selected during aging tests.

\begin{tabular}{ccccc}
\hline No. & Temperature $\left[{ }^{\circ} \mathbf{C}\right.$ ] & Discharging Current [A] & Depth of Discharge [\%] & Performed Cycle Number [-] \\
\hline 1 & 25 & 2.6 & 100 & 1800 \\
2 & 25 & 5.2 & 100 & 1070 \\
3 & 25 & 7.8 & 100 & 580 \\
4 & 25 & 10.5 & 100 & 410 \\
5 & 15 & 2.6 & 100 & 595 \\
6 & 15 & 5.2 & 100 & 180 \\
7 & 15 & 5.2 & 50 & 1075 \\
8 & 15 & 7.8 & 100 & 1300 \\
9 & 40 & 2.6 & 100 & 1170 \\
10 & 40 & 5.2 & 100 & 678 \\
11 & 40 & 7.8 & 100 & 395 \\
12 & 40 & 7.8 & 77 & 776 \\
13 & 40 & 7.8 & 50 & 1321 \\
14 & 40 & 7.8 & 27 & 2473 \\
\hline
\end{tabular}

The state of health of the cell is defined as the ratio of the current capacity of the $\mathrm{C}_{\text {act }}$ cell (determined in control conditions on the basis of relation 8 ) to the capacity of the new $C_{n e w}$ cell. The condition for the completion of each aging test was a cell wear of $20 \%$, which corresponds to a cell $S O H=80 \%$. After the cell reached $S O H=80 \%$, the number of complete charging cycles was noted. Capacity control measurements for each variant were performed every several dozen cycles. The control conditions are set out in Table 3.

$$
S O H=\frac{C_{a c t}}{C_{\text {new }}} \cdot 100 \%
$$

Table 3. The test conditions for measuring cell capacity.

\begin{tabular}{cc}
\hline Parameter & Value \\
\hline Ambient temperature & $2{ }^{\circ} \mathrm{C}$ \\
Discharge current & $2.6 \mathrm{~A}$ \\
Initial charging current & $1.3 \mathrm{~A}(\mathrm{CC}-\mathrm{CV}$ mode, at CV cell was charging till \\
Discharge depth & current reach $0.05 \%$ initial value $)$ \\
Upper/lower cut-off voltage & $100 \%$ \\
\hline
\end{tabular}

\subsection{Impact of Ambient Temperature on Cycle Life}

Test results from $15{ }^{\circ} \mathrm{C}, 25^{\circ} \mathrm{C}, 40^{\circ} \mathrm{C}, 2.6 \mathrm{~A}$ discharge current and $100 \%$ discharge depth were used to investigate the effect of ambient temperature on the cell's SOH. In these tests, the cell performed 595, 1800 , and 1170 complete cycles (nos 1, 5, 9, Table 2) respectively before reaching SOH $=80 \%$. On the basis of the obtained results, it was found that the cell is characterized by higher wear at temperatures below $20^{\circ} \mathrm{C}$ and above $35^{\circ} \mathrm{C}$. For this reason, we proposed to use the Gauss function (Equation 9) as a function of temperature impact (with other cyclic parameters remaining constant) on the number of cell cycles. The course of the Gauss function is shown in Figure 1.

$$
N(T)=a \cdot e^{\left(-\left(\frac{T-b}{c}\right)^{2}\right)}
$$

where $\mathrm{N}$ is the number of cycles; $\mathrm{T}$ is the ambient temperature; and $\mathrm{a}, \mathrm{b}, \mathrm{c}$ are coefficients. 


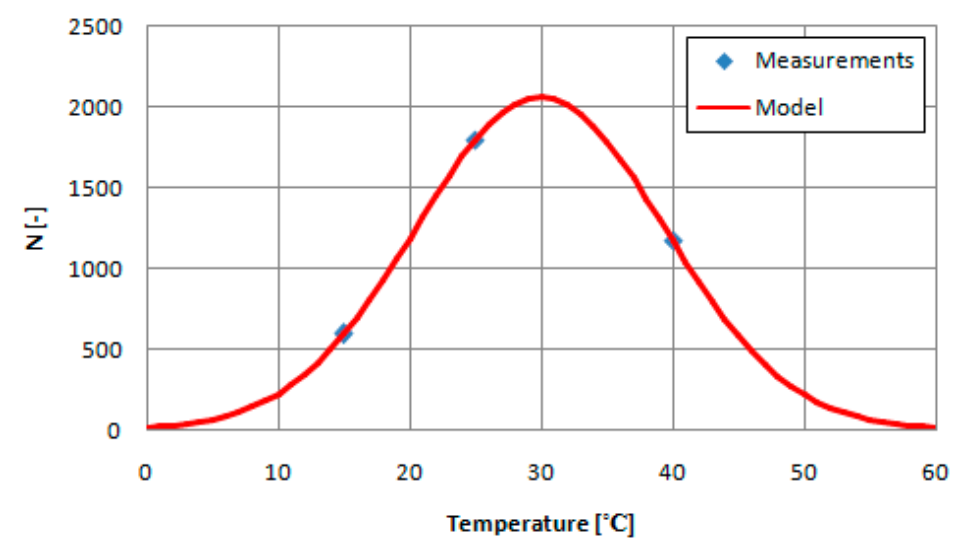

Figure 1. Impact of ambient temperature on cell cycle number.

\subsection{Impact of Discharging Current on Cycle Life}

Test results obtained at $25^{\circ} \mathrm{C}$ were used to investigate the effect of the discharge current on the number of cell cycles after which the cell is considered to be worn out. In these tests, for discharge currents of 2.6, 5.2, 7.8, and 10.5 A, the cell made 1800, 1070, 580, and 410 cycles respectively (nos 1-4, Table 2). On the basis of the tests performed, the power function described in Relation 10 was selected for the discharge current because it best represented the influence of this factor on the number of cell cycles (Figure 2).

$$
N\left(I_{d}\right)=d \cdot\left(I_{d}\right)^{e}+f
$$

where $N$ is the number of cycles; $I_{d}$ is the discharging current; and $d, e, f$ are model coefficients.

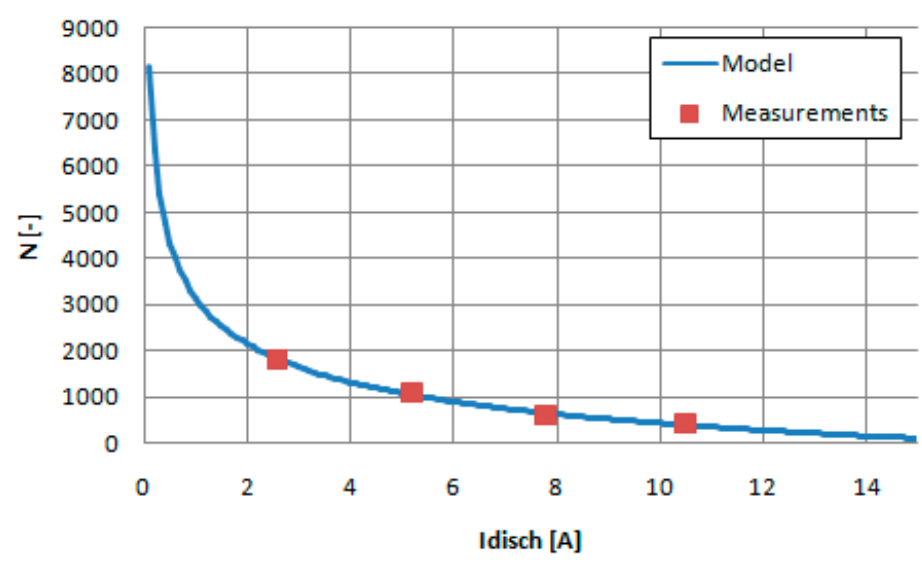

Figure 2. Impact of discharging current on cell cycle number.

\subsection{Impact of Depth of Discharge on Cycle Life}

For the analysis of the influence of $D O D$ on the number of cell cycles, variants nos 11-14 from Table 2 were used. The ambient temperature during these tests was $40{ }^{\circ} \mathrm{C}$ and the discharge current was 7.8 A. For DOD equal to $27 \%, 50 \%, 77 \%$, and $100 \%$, the cell made $2473,1321,776$, and 395 complete cycles respectively. As in the case of the discharge current, the function that best represents the influence of $D O D$ is the power function, Equation 11, Figure 3.

$$
N(D O D)=g \cdot(D O D)^{h}+i
$$

where $N$ is the number of cycles; $D O D$ is the depth of discharge; and $g, h, i$ are coefficients. 


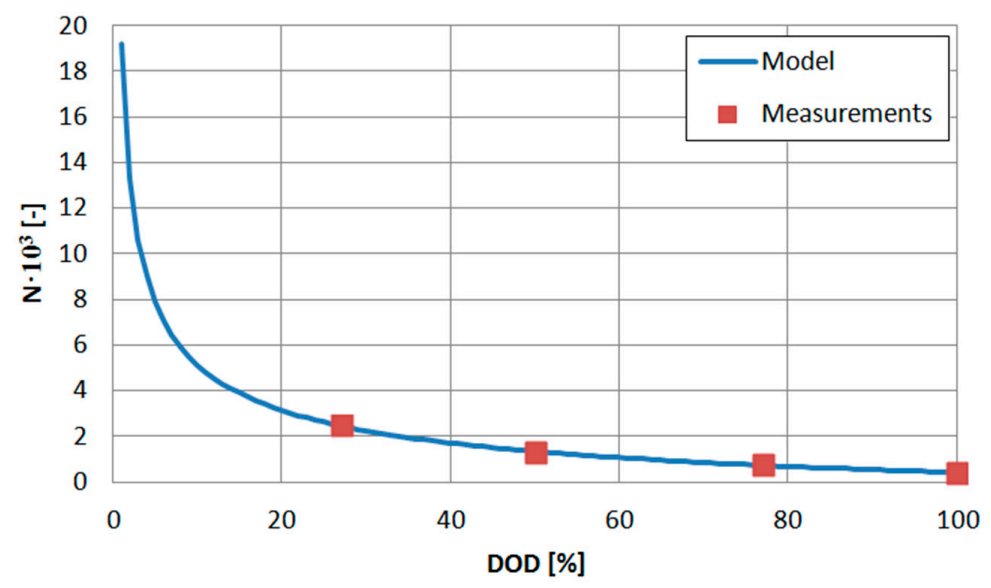

Figure 3. Impact of depth of discharge on cell cycle number.

\subsection{Estimation of Model Coefficients}

The function coefficients, 9-11, were estimated using the method of least squares. The total square error between the measured value and the value determined by the model was minimized (Equation (12)). For the obtained coefficients (Equations 9-11) this was, respectively: 8.5737e-22, 6105, and 3038, which corresponds to a determination factor of $1,0.9948$, and 0.9988 . The estimated values of the coefficients are presented in Table 4.

$$
S S E=\min \left\{\sum\left(y_{\text {meas }}^{2}-y_{\text {model }}^{2}\right)\right\}
$$

where SSE is the sum of squares errors, $y_{\text {meas }}$ is the measured value, and $y_{\text {model }}$ is the value calculated from Equations 9-11.

Table 4. Results of estimation of function coefficients in eqs. 9-11.

\begin{tabular}{cccc}
\hline Coefficient & Value & Coefficient & Value \\
\hline a & 2061 & $\mathrm{f}$ & -2758 \\
$\mathrm{~b}$ & 29.93 & $\mathrm{~g}$ & 21180 \\
$\mathrm{c}$ & 13.39 & $\mathrm{~h}$ & -0.475 \\
$\mathrm{~d}$ & 5897 & $\mathrm{i}$ & -1959 \\
$\mathrm{e}$ & -0.2683 & & \\
\hline
\end{tabular}

\section{NMC Cells Wear Process Modeling Using Fuzzy Logic}

Fuzzy logic is an approach belonging to multivalent logic. It assumes that there are many intermediate values between the logical zero and the logical one, which determine the degree of belonging of the element to the set. Fuzzy systems are characterized by the fact that they are knowledge-based models, which is their greatest advantage. At the same time, their implementation does not require knowedge of the details of the chemical aging reactions taking place in the cell or prior determination of function coefficients defining the impact of cyclic operating parameters on the process of cell wear, which is often very difficult. Two classes of fuzzy systems can be distinguished, the Mamdani type and the Takagi-Sugeno-Kang type [28].

\subsection{Methodology of Fuzzy Modeling}

The classic fuzzy system scheme consists of the following four blocks: fuzzification, inference, base of rules, and defuzzification. Its structure is presented in Figure 4.

In the fuzzification block, for each real value of input parameter, $x_{i}$, of the model, the degree of membership to individual sets of fuzzy input, $A_{i}$, is calculated. A fuzzy set in a certain space of considerations, $\mathrm{X}$, is a set of pairs: 


$$
\mathrm{A}_{\mathrm{i}}=\left\{\left(\mu_{A}^{*}\left(x_{i}\right), x_{i}\right)\right\}, \forall x_{i} \in X
$$

where $\mu_{A}$ is the membership function of fuzzy set $\mathrm{A}$.

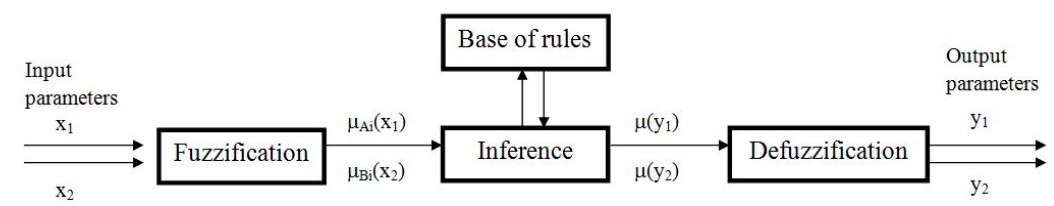

Figure 4. Classical structure of a fuzzy system.

Membership functions assign to each input parameter, $\mathrm{x}_{\mathrm{i}} \in X$, the degree of its belonging, $\mu_{A}^{*}\left(x_{i}\right)$, to a fuzzy set, assuming that $\mu_{A}\left(x_{i}\right) \in[0,1]$.

In a block of inferences on the basis of input degrees of membership $\mu_{A}^{*}\left(x_{i}\right)$, the resultant function of belonging is calculated $\mu_{r e s}\left(y_{i}\right)$ for each output of the $y_{i}$ model. The character of the resultant function of membership is most frequently complex. Its calculation is done through reasoning, which can be mathematically realized in many ways. In order to carry out the inference operation, the inference block must contain a database of defined rules, the inference mechanism and the membership functions $\left(B_{i}\right)$ of the output of the model $(y)$. The base of rules contains logical rules that define cause and effect dependencies existing in the system between sets of fuzzy inputs and outputs. It takes the form of conditional sentences of the type:

$$
\text { If } x_{i} \text { is } A_{i} \text { And ... And } x_{n} \text { is } A_{n} \text { Then } y_{i} \text { is } B_{j} \text { And ... And } y_{m} \text { is } B_{m}
$$

where $x_{i}$ is the value of $\mathrm{i}$-th input parameter, $A_{i}$ is the $\mathrm{i}$-th fuzzy set of conditions, $B_{j}$ is the $\mathrm{j}$-th fuzzy set of conclusions, $y_{i}$ is the value of $\mathrm{i}$-th output parameter, and $n / m$ is the number of input/output parameters.

In the defuzzification block, a mechanism of defuzzification is implemented which, on the basis of the resulting function of belonging $\mu\left(y_{i}\right)$, determines the crisp value of each output of the $y_{i}$ model. There are many methods of defuzzification, the most popular of which include the following: middle of maxima, centre of gravity, centre of sums, and the height method. For example, in the centre of gravity method, the sharp output value of model $y$ is determined as the centre of gravity of the surface under the curve defined by this function (Figure 5), and is calculated as the quotient of the momentum of the area under the curve $\mu_{\text {res }}(y)$ relative to the vertical axis $\mu(y)$ and the size of that area. The relationship is as follows:

$$
y=\frac{\int y \cdot \mu_{r e s}(y) d y}{\int \mu_{r e s}(y) d y}
$$

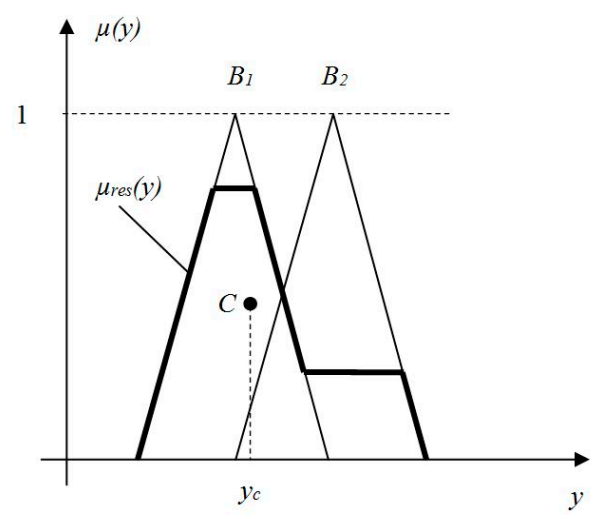

Figure 5. Defuzzification by the centre of gravity method. 


\subsection{A Fuzzy Model of the NMC Cell Wear Process}

In order to model the wear process of NMC cells (with the parameters given in Section 4) under constant load conditions, it is proposed to use a fuzzy Mamdani system. The input parameters of the model are the operating parameters of the cyclic cell (half-cycle discharge), i.e., ambient temperature, value of discharge current, and depth of discharge. The model assumes that in each half-cycle of charging, cells are charged with a constant current with a mean value of $0.85 \mathrm{C}$ up to a final voltage of $4.2 \mathrm{~V}$. The output parameter of the model is the number of full $\mathrm{N}$ cycles of charging that the cell can perform before it reaches the wear indicator equal to $\mathrm{SOH}=80 \%$. For each input parameter of the model, three triangular membership functions were defined (Figure $6 \mathrm{a}-\mathrm{c}$ ), while for the number of $N$ cell cycles, using the results of tests presented in Section 4, nine triangular membership functions were defined (Figure 6d).

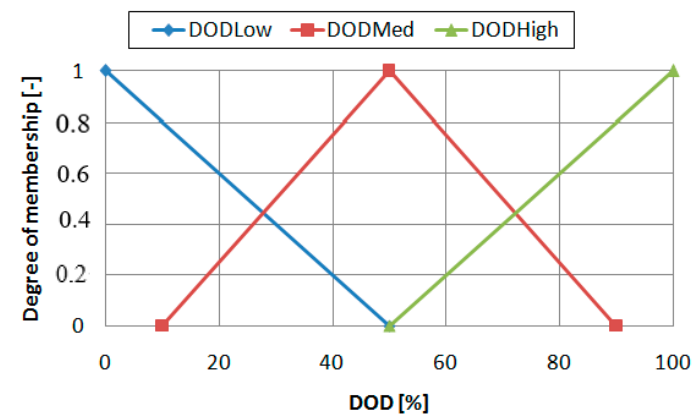

a)

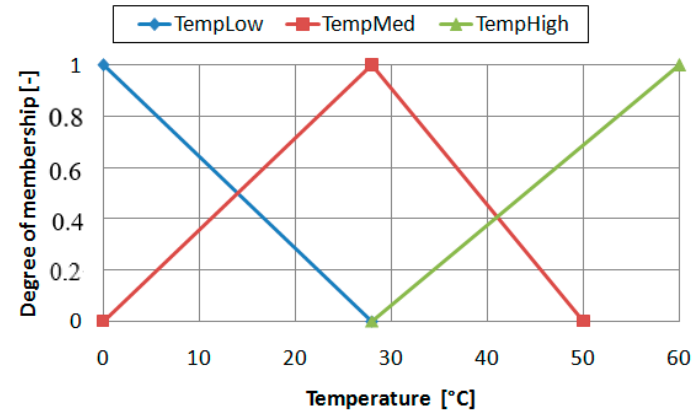

c)

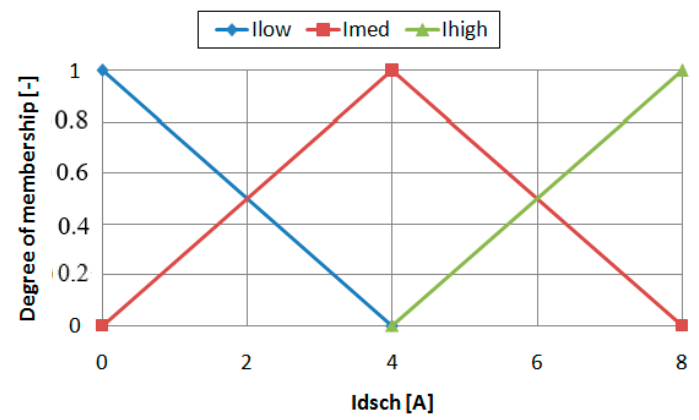

b)

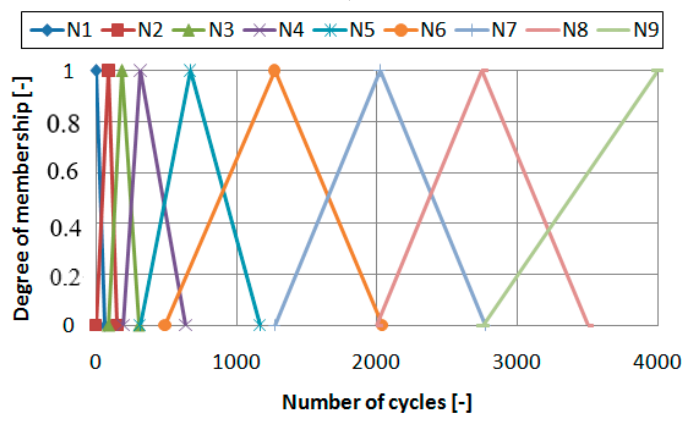

d)

Figure 6. Membership functions of model parameters: (a) depth of discharge, (b) discharging current, (c) temperature, and (d) number of cycles.

The function of minimum (Equation 16) was assumed as t-norm operators in the inference process, whereas the function of maximum (Equation 17) was assumed as s-norm operators in the aggregation process. The centre of gravity method was used as a method of defuzzification [28].

$$
\begin{aligned}
& \mu_{A \cap B}(x)=\min \left\{\mu_{A}(x), \mu_{B}(x)\right\} \\
& \mu_{A \cup B}(x)=\max \left\{\mu_{A}(x), \mu_{B}(x)\right\}
\end{aligned}
$$

The base of rule of model contains 27 linguistic rules, based on which the number of cycles is inferred. This takes into account the measurement results (Table 2) and contains all possible combinations of functions belonging to the input parameters of the model.

An illustration of the process of applying a fuzzy model of cell wear is presented in Figure 7a-c. 


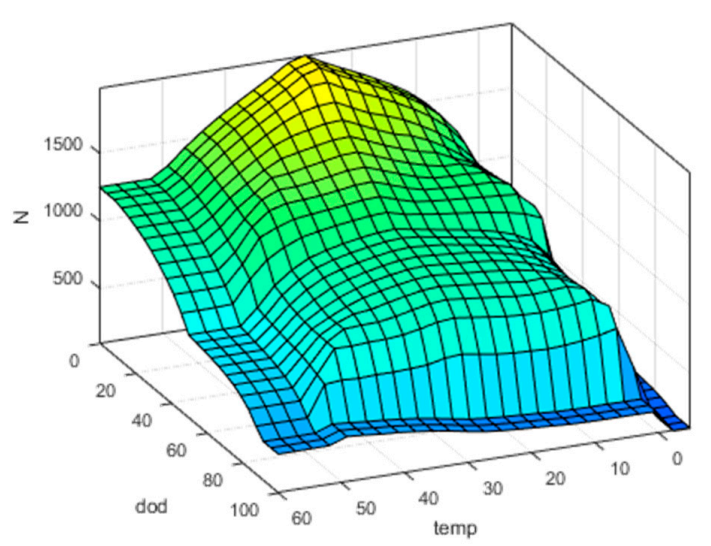

a)

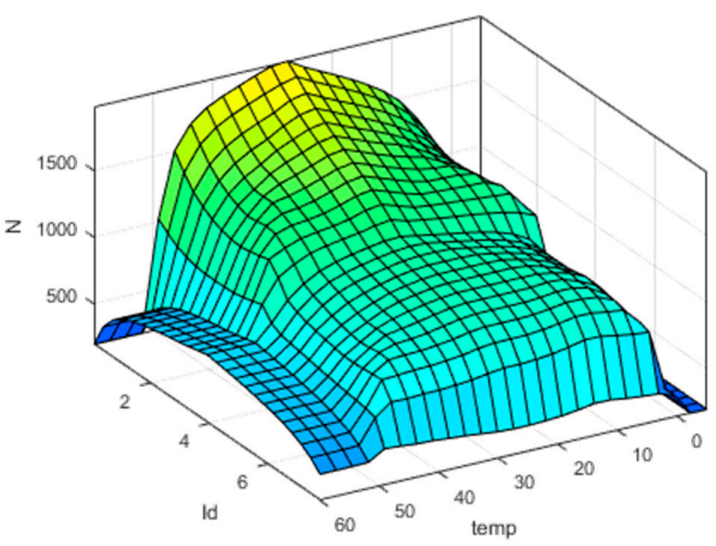

b)

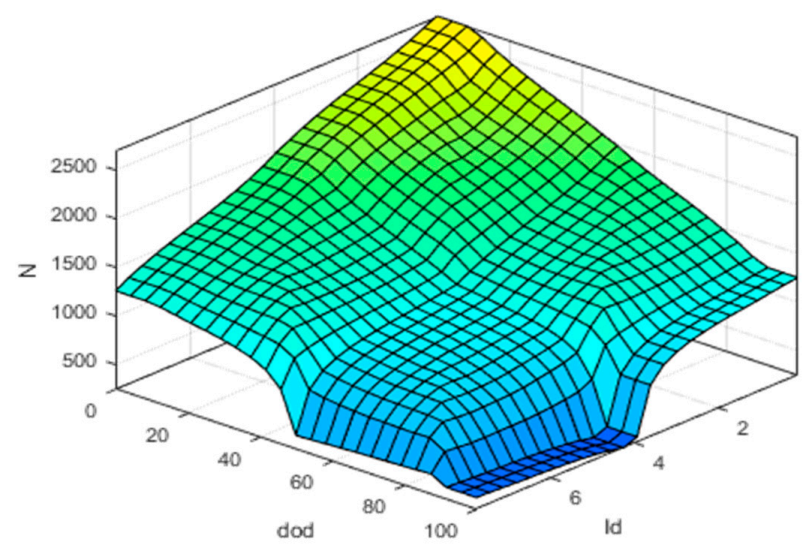

c)

Figure 7. Illustration of the inference process of the model: (a) number of cycles vs depth of discharge and temperature, (b) number of cycles vs discharging current and temperature, and (c) number of cycles vs depth of discharge and discharging current.

The developed model has been verified for six different combinations of cyclic cell operating parameters. The accuracy of the model was determined by a relative error derived from:

$$
R E=\left(\frac{y_{\text {meas }}-y_{\text {model }}}{y_{\text {meas }}}\right) \cdot 100
$$

The verification results are summarized in Table 5.

Table 5. Verification results of NMC cell wear from fuzzy model

\begin{tabular}{ccccccc}
\hline No. & $\begin{array}{c}\text { Temperature } \\
{\left[{ }^{\circ} \mathrm{C}\right]}\end{array}$ & $\begin{array}{c}\text { Discharging } \\
\text { Current [A] }\end{array}$ & $\begin{array}{c}\text { Depth of } \\
\text { Discharge } \\
{[\%]}\end{array}$ & $\begin{array}{c}\text { Simulated } \\
\text { Number of } \\
\text { Cycles [-] }\end{array}$ & $\begin{array}{c}\text { Real } \\
\text { Number of } \\
\text { Cycles [-] }\end{array}$ & $\begin{array}{c}\text { Relative } \\
\text { Error [\%] }\end{array}$ \\
\hline 1 & 25 & 2.6 & 100 & 1705 & 1800 & 5.60 \\
2 & 40 & 7.8 & 27 & 2152 & 2473 & 14.89 \\
3 & 40 & 7.8 & 100 & 433 & 395 & 8.84 \\
4 & 40 & 7.8 & 50 & 1374 & 1321 & 3.84 \\
5 & 15 & 2.6 & 100 & 559 & 595 & 6.37 \\
6 & 15 & 7.8 & 100 & 1385 & 1300 & 6.13 \\
\hline
\end{tabular}

For most of the verified variants, the relative model error is below $10 \%$. This proves the correct operation of the fuzzy algorithm and its usefulness for predicting the aging process of cells. For the 
variant $I_{d}=7.8 \mathrm{~A}, T=40^{\circ} \mathrm{C}, D O D=27 \%$, and the relative error was $14.89 \%$. It seems that this is a big inaccuracy, but the number of cycles performed by cells operating with reduced $D O D$ is always many times greater than during full discharge and is often characterized by a large spread (in the case of $D O D$ below $20 \%$, the difference in the number of cycles performed can reach up to several thousand cycles). For this reason, all the results obtained should be considered satisfactory.

\section{Conclusions}

This paper describes the analyses of modeling the process of wear of 18650 lithium-ion NMC cells during cyclic operation under constant load conditions. Modeling the process of wear of NMC cells is a complex issue due to the need to take into account a large number of cyclic parameters and the correct representation of the degree of their impact. For this reason, determining the structure of the model is complex and often requires simplifying assumptions. On the basis of accelerated aging tests, the influence of discharging parameters on the process of cell capacity atrophy was investigated. In addition, functions were developed to characterize the impact of these parameters on the number of cell cycles before it reaches wear level. For ambient temperature, a new type of function reflecting the Gauss function was proposed (Equation 9), from the obtained results, the highest number of cycles a cell can perform (assuming other cyclic parameters remain constant) at a temperature close to $30^{\circ} \mathrm{C}$. In the case of discharge current and $D O D$ values, the number of cycles depends on the power function on these parameters. The use of a fuzzy Mamdani system to reproduce the wear process of a cyclic operating cell yielded satisfactory results. For the verified variants (Table 5), in most cases the relative model error was less than $10 \%$. In our opinion, bearing in mind the complexity of modeling the process of cell wear, this is an acceptable value.

Future research should focus on reducing model error by including charging current, $S O C_{a v g}$, and upper cut-off voltage in the model.

Author Contributions: Conceptualization, D.B.; methodology, D.B. and L.K.; validation, L.K., D.B., and A.T.; formal analysis, A.T. and L.K.; resources, D.B.; data curation, D.B.; writing-original draft preparation, D.B. and R.P.; writing_-review and editing, D.B. and L.K., and R.P.; visualization, D.B.; supervision, L.K. and A.T.

Funding: This research was funded by the Polish Government, grant number [04/42/SBAD/0483].

Conflicts of Interest: The authors declare no conflict of interest.

\section{References}

1. Tomczewski, A.; Kasprzyk, L.; Nadolny, Z. Reduction of power production costs in a wind power plant-flywheel energy storage system arrangement. Energies 2019, 12, 1942. [CrossRef]

2. Kasprzyk, L.; Domeracka, A.; Burzyński, D. Modelling of lithium-ion batteries operation and life in electric vehicles. Prz. Elektrotech. 2018, 94, 160-163. [CrossRef]

3. Burzyński, D.; Głuchy, D.; Godek, M. Analysis of the impact of quick charge technology on the charging process parameters of the lithium-ion storage at various temperatures. In ITM Web of Conferences; EDP Sciences: Les Ulis, France, 2018; Volume 19.

4. Burzyński, D.; Kasprzyk, L. The operation and capacity fade modelling of the lithium-ion cell for electric vehicles. In E3S Web of Conferences; EDP Sciences: Les Ulis, France, 2019; Volume 108, p. 01017.

5. Burzyński, D.; Kasprzyk, L. Selected methods of modelling of the electrochemical cells operation. Prz. Elektrotech. 2017, 93, 75-78.

6. Burzyński, D.; Kasprzyk, L. Analysis of the potential use of lithium-ion energy storage in the home charging station for electric cars. In IOP Conference Series: Earth and Environmental Science; IOP Publishing: Bristol, UK, 2019; Volume 214, p. 012077.

7. Kasprzyk, L. Modelling and analysis of dynamic states of the lead-acid batteries in electric vehicles. Eksploat. Niezawodn. Maint. Reliab. 2017, 19, 229-236. [CrossRef]

8. Hu, X.; Li, S.; Peng, H. A comparative study of equivalent circuit models for Li-ion batteries. J. Power Sources 2012, 198, 359-367. [CrossRef] 
9. Omar, N.; Monem, M.A.; Firouz, Y.; Salminen, J.; Smekens, J.; Hegazy, O.; Gaulous, H.; Mulder, G.; van den Bossche, P.; Coosemans, T.; et al. Lithium iron phosphate based battery-Assessment of the aging parameters and development of cycle life model. Appl. Energy 2014, 113, 1575-1585. [CrossRef]

10. Leng, Y.; Ge, S.; Marple, D.; Yang, X.; Bauer, C.; Lamp, P.; Wang, C. Electrochemical cycle-life characterization of high energy lithium-ion cells with thick $\mathrm{Li}\left(\mathrm{Ni}_{0.6} \mathrm{Mn}_{0.2} \mathrm{Co}_{0.2}\right) \mathrm{O}_{2}$ and graphite electrodes. J. Electrochem. Soc. 2017, 164, 1037-1049. [CrossRef]

11. Xu, B.; Oudalov, A.; Ulbig, A.; Andersson, G.; Kirschen, D.S. Modeling of lithium-ion battery degradation for cell life assessment. IEEE Trans. Smart Grid 2018, 9, 1131-1140. [CrossRef]

12. Huang, S.; Tseng, K.; Liang, J.; Chang, C. An online SOC and SOH estimation model for lithium-ion batteries. Energies 2017, 10, 512. [CrossRef]

13. Keil, P.; Schuster, S.F.; Wilhelm, J.; Travi, J.; Hauser, A.; Karl, R.C.; Jossen, A. Calendar aging of lithium-ion batteries. J. Electrochem. Soc. 2016, 163, A1872-A1880. [CrossRef]

14. Kaneko, G.; Inoue, S.; Taniguchi, K.; Hirota, T.; Kamiya, Y.; Daisho, Y.; Inami, S. Analysis of degradation mechanism of lithium iron phosphate battery. World Electr. Veh. J. 2013, 6, 555-561. [CrossRef]

15. Barré, A.; Suard, F.; Gérard, M.; Montaru, M.; Riu, D. Statistical analysis for understanding and predicting battery degradations in real-life electric vehicle use. J. Power Sources 2014, 245, 846-856. [CrossRef]

16. Schmalstieg, J.; Käbitz, S.; Ecker, M.; Sauer, D.U. A holistic aging model for Li(NiMnCo)O ${ }_{2}$ based 18,650 lithium-ion batteries. J. Power Sources 2014, 257, 325-334. [CrossRef]

17. Liu, T.; Cheng, L.; Pan, Z.; Sun, Q. Cycle life prediction of lithium-ion cells under complex temperature profiles. Ekspolat. Niezawodn. Maint. Reliab. 2016, 18, 25-31.

18. Han, X.; Ouyang, M.; Lu, L.; Li, J. Cycle life of commercial lithium-ion batteries with lithium titanium oxide anodes in electric vehicles. Energies 2014, 7, 4895-4909. [CrossRef]

19. Cui, Y.; Du, C.; Yin, G.; Gao, Y.; Zhang, L.; Guan, T.; Yang, L.; Wang, F. Multi-stress factor model for cycle lifetime prediction of lithium ion batteries with shallow-depth discharge. J. Power Sources 2015, 279, $123-132$. [CrossRef]

20. Kasprzyk, L. Wybrane zagadnienia modelowania ogniw elektrochemicznych i superkondensatorów w pojazdach elektrycznych. Pozn. Univ. Technol. Acad. J. 2019, 101. [CrossRef]

21. Gao, Y.; Jiang, J.; Zhang, C.; Zhang, W.; Ma, Z.; Jiang, Y. Lithium-ion battery aging mechanisms and life model under different charging stresses. J. Power Sources 2017, 356, 103-114. [CrossRef]

22. Santhanagopalan, S.; Kim, G.H.; Keyers, M.; Pesaran, A.; Smith, K.; Neubauer, J. Battery life. In Design and Analysis of Large Lithium-Ion Battery Systems; Artech House: London, UK, 2015; pp. 81-93.

23. Jossen, A. Fundamentals of battery dynamics. J. Power Sources 2006, 154, 530-538. [CrossRef]

24. Birkl, C.R.; Roberts, M.R.; McTurk, E.; Bruce, P.G.; Howey, D.A. Degradation diagnostics for lithium ion cells. J. Power Sources 2017, 341, 373-386. [CrossRef]

25. Bach, T.C.; Schuster, S.F.; Fleder, E.; Müller, J.; Brand, M.J.; Lorrmann, H.; Jossen, A.; Sextl, G. Nonlinear aging of cylindrical lithium-ion cells linked to heterogeneous compression. J. Energy Storage 2016, 5, 212-223. [CrossRef]

26. Schuster, S.F.; Bach, T.; Fleder, E.; Müller, J.; Brand, M.; Sextl, G.; Jossen, A. Nonlinear aging characteristics of lithium-ion cells under different operational conditions. J. Energy Storage 2015, 1, 44-53. [CrossRef]

27. Wang, J.; Purewal, J.; Liu, P.; Hicks-garner, J.; Soukazian, S.; Sherman, E.; Sorenson, A.; Vu, L.; Tataria, H.; Verbrugge, M.W. Degradation of lithium ion batteries employing graphite negatives and nickel-cobalt-manganese oxide + spinel manganese oxide positives: Part 1, aging mechanisms and life estimation. J. Power Sources 2014, 269, 937-948. [CrossRef]

28. Zadeh, L.A. The concept of a linguistic variable and its application to approximate reasoning-I. Inf. Sci. 1975, 8, 199-249. [CrossRef]

(C) 2019 by the authors. Licensee MDPI, Basel, Switzerland. This article is an open access article distributed under the terms and conditions of the Creative Commons Attribution (CC BY) license (http://creativecommons.org/licenses/by/4.0/). 